\title{
Understanding Individual Tax Compliance: Advanced Deductions And Related Issues
}

Kevin E. Flynn, West Chester University of Pennsylvania, USA Phyllis Belak, West Chester University of Pennsylvania, USA

Glenn Soltis, West Chester University of Pennsylvania, USA

\begin{abstract}
We present a realistic, complex, flexible, classroom-friendly tax case study that is designed to be a late semester comprehensive assignment in a student's federal income tax education. The assignment could be used as a template when teaching students how to prepare a federal individual income tax return using the actual forms and schedules prepared by the Internal Revenue Service (IRS). This case is relevant for two reasons: 1) it is contemporary in that it consists of the most recent tax year (2013), and 2) it is highly useful as it comprehensively examines concepts typically covered in the later chapters of a tax text - most itemized deductions, purchase and sale of a residence, casualty and theft loss, moving expenses, employee business expenses, education tax credits, and investment property - while only reviewing information found in earlier chapters. In addition, the case is flexible so that it can be used in future years with only slight modifications for tax law changes.
\end{abstract}

Keywords: Tax Case Study; Tax Education; Sale of a Residence; Casualty and Theft Loss; Employee Business Expenses; Education Tax Credits; Investment Property

\section{INTRODUCTION}

C n extant literature, there are few tax return teaching tools appearing in journals. Accordingly, we have developed a realistic, complex, flexible, classroom-friendly case that could be used by an instructor as a template when teaching students how to prepare a federal income tax return using the actual forms and schedules prepared by the Internal Revenue Service (IRS). The case can be used in an individual federal income tax course at either the undergraduate or graduate level. Our motivation for developing this case is to make a tax return assignment a more effective teaching tool. Our case focuses primarily on the concepts that are covered in the later stages of a federal income tax course and eliminates the ability of the student to obtain access to the solution before completing the assignment. This teaching tool was initially tested during the 2009-2010 academic year. A version of this case has been used in the classroom every year since that first year, and has reached the point where it is refined only minimally each time it is used in a tax course. This case has received overwhelmingly positive feedback from students.

Our case is timely for two reasons. First, we want a teaching tool that matches the concepts being covered within the course at a specific point in the semester. End of chapter textbook tax return problems typically involve concepts that are not covered in the chapter in which the tax return problem is assigned. For example, early-semester tax return assignments in textbooks typically include concepts not yet learned (i.e., itemized deductions). Or, latesemester tax return problems include concepts previously learned that do not need to appear on a late-semester assignment (i.e., various forms of income and deductions for adjusted gross income). It can be argued that including concepts covered early in the semester on a late-semester assignment simply reinforces those concepts learned. However, including too many concepts in an assignment tends to make it overly complex, which leads to student frustration resulting in the breakdown of learning. In order to develop an effective tax return assignment, a professor walks a line between including sufficient concepts to make the assignment effective and excluding too many concepts such that it makes the assignment ineffective. We feel it is important that a tax return assignment focus on 
the concepts being reviewed in the current chapters of the text being covered. Therefore, the case developed in this paper focuses on concepts covered in the later portion of an individual federal income tax course.

Our second motivation for developing this case template is to have a comprehensive assignment where the student does not already have the solution. With the availability of information on the internet, students have greater access to textbook assignment solutions. This availability of solutions coupled with the growing proliferation of academic dishonesty tends to render textbook assignments ineffective as a learning tool. Academic dishonesty is more prevalent in collegiate classrooms and has received added attention in recent years by researchers, administrators, and the media. According to a recent study by the Center for Academic Integrity, more than 75 percent of college students admitted to engaging in some form of cheating (Smith, Davy, \& Rosenberg, 2009). Thus, we developed a comprehensive case where the instructor could change the variables (numbers) and/or concepts and the students would not have access to the solution, thereby forcing the student to churn through the assignment and thus learn the concepts, which is not accomplished when a student simply copies the solution.

To address these concerns, we began developing our own tax return assignments in the summer of 2009 . We first tested this case in an undergraduate federal income tax course during the Fall 2009 - Summer 2010 academic year. It was refined and tested again during the $2010-2011,2011-2012$, and $2012-2013$ academic years. The assignment received positive feedback from students who consider it to be challenging without being overwhelming. In addition, it provided students with valuable experience by illustrating how concepts learned in the classroom appear on IRS forms and schedules. In other words, it teaches students how to comply with the rules and regulations established by the federal government. Furthermore, students learn what information appears in various reference resources that are available to them, and how to use those resources.

In a recent year, the American Institute of Certified Public Accountants (AICPA) developed a Model Tax Curriculum (MTC) that many schools have implemented. The MTC recommends that curriculums emphasize business entity income taxation. Further, the MTC focuses on a business planning and decision making approach rather than a compliance approach. This paper attempts to supplement the business planning decision making focus of the MTC.

Despite the AICPA's recommendation to implement the MTC, the tax curriculums at universities vary widely. According to a survey published in The Tax Adviser, 29\% of undergraduate accounting programs now require only one tax course, plus $44 \%$ require one tax course and offer a second tax course as an elective. In addition, $12 \%$ require two tax courses and $10 \%$ offer more than two courses at the undergraduate level. However, the survey found that even at institutions offering only one tax course, individual income taxation is still highly emphasized (Nellen, Kern, \& Dennis-Escoffier, 2004). As a result, the teaching tool introduced in this paper should have widespread appeal to tax instructors.

The remaining sections of this paper explain the learning objectives, the case materials, teaching notes that offer additional explanations to clarify issues, the solution, and the actual tax return that should be prepared by the students.

\section{LEARNING OBJECTIVES}

This case is designed to be a late-semester, comprehensive tax return assignment that covers the concepts generally taught in the later chapters in a federal income taxation text. The assignment coverage includes: selling and buying a principal residence, paying for a college education, purchasing investment property, incurring personal casualty and theft losses, and paying for various expenses that qualify as itemized deductions.

We suggest the instructor require students to manually complete the tax return. We posit that by manually preparing a return, students are better able to 1) visualize how textbook concepts appear on forms and schedules in an actual tax return, and 2) best learn how the forms, schedules, and supporting documentation relate to each other. Students that prepare a tax return using a tax software program simply learn how to enter information into that software's input screen on a computer. Different firms use different software programs so we feel that teaching 
students how to use one program may hinder their professional growth, and that they are better served by preparing the assignment manually. We have received the following anecdotal evidence to suggest that this is the best approach. Students, both current and former, who work in the tax departments of CPA firms, have indicated to us that they quickly learn how to use a tax software program. In addition, they have a better idea how to complete a tax return - plus they are better at catching and rectifying tax software program errors - as a result of preparing their tax return assignments manually while they were students. Instructors should provide this justification to students when assigning the problem. However, if an instructor either requires or allows students to use tax software when preparing a tax return assignment, it would help the students' comprehension either to list how the forms tie together or to print out the forms and assemble them in the proper order.

Upon completion of this case, a student understands how to:

1. Identify and report multiple dependents.

2. Report a dependent that is eligible for the Child Tax Credit.

3. Include interest income, both taxable interest and tax-exempt interest, on both the Form 1040 and Schedule B.

4. Report the sale of a residence, and the corresponding purchase of a new residence.

5. Apportion real property taxes between the buyer and the seller of a residence.

6. $\quad$ Determine what costs qualify as selling expenses when selling a residence.

7. Determine what costs are added to the basis of a residence at the time of purchase.

8. Determine what expenditures qualify as capital expenditures, and are thus added to the basis.

9. Report a moving expense deduction.

10. Report contributions to a traditional IRA (individual retirement account).

11. Compute the tax liability when the long-term capital gain alternative tax is used.

12. Recognize a credit for Child and Dependent Care Expenses.

13. Report an education tax credit - the American Opportunity Credit.

14. Compute and record the American Opportunity Credit phaseout.

15. Recognize when the Child Tax Credit is completely phased out.

16. Report a refund that includes a portion deposited directly into a bank account, and a portion applied to next year's tax liability.

17. Attach a schedule to the back of the return when information does not fit on the IRS form or IRS schedule.

18. Use the Sales Tax Tables to determine the sales tax deduction.

19. Report the following itemized deductions:

a. State and local income tax payments.

b. Property tax payments.

c. Home mortgage loan interest.

d. Points paid, both prepaid interest and fees, when obtaining a new mortgage loan.

e. Investment interest expense.

f. Charitable contributions.

g. Personal casualty and theft losses.

h. Unreimbursed employee travel expenses.

i. Union dues.

j. Professional subscriptions.

k. Professional membership dues.

1. Business gifts.

m. Tax preparation fees.

n. Gambling losses.

\section{THE CASE}

Hercules W. Hoomanawanui, Jr. (age 48) and his wife Henrietta R. Hoomanawanui (age 47) live at 8426 North Carancahua Street, Corpus Christi, TX 78401. They have been married for 24 years and have filed a joint return each of those 24 years. Hercules is employed as an accountant at Dewey, Cheatum, \& Howe, $169 \mathrm{~S}$. 
Navigation Blvd., Corpus Christi, TX 78402, while Henrietta is employed as a financial analyst with TD Ameritrade, 936 Coral Drive, Kingsville, TX 78363. Both Hercules and Henrietta want to contribute $\$ 3$ to the presidential election campaign fund. Their daytime phone number is 361-835-1436. If Hercules and Henrietta are owed a refund, they want the first $\$ 500$ applied to their next year's federal income tax liability. They want any residual amount above $\$ 500$ deposited directly into their savings account. The savings account number is 3692581740 , and the bank's routing number is 031000011 .

The following information appears on Hercules and Henrietta's Wage and Tax Statements (Form W-2) for 2013. Hercules had two employers in 2013. Therefore, the information shown for him is from his two employers combined.

\begin{tabular}{clrr} 
Line & \multicolumn{1}{c}{ Description } & Hercules & Henrietta \\
\hline 1 & Wages, tips, other compensation & $\$ 79,000$ & $\$ 67,000$ \\
2 & Federal income tax withheld & 4,740 & 4,020 \\
3 & Social Security wages & 79,000 & 67,000 \\
4 & Social Security tax withheld & 3,318 & 2,814 \\
5 & Medicare wages and tips & 79,000 & 67,000 \\
6 & Medicare tax withheld & 1,145 & 972 \\
14 & Union dues & & 670 \\
16 & State wages, tips, etc. & & \\
17 & State income tax withheld & 79,000 & 67,000 \\
18 & Local wages, tips, etc. & 790 & 670 \\
19 & Local income tax withheld & &
\end{tabular}

Hercules and Henrietta support the following children who live at home with them (ages as of December 31, 2013): triplets Herman, Hermione, and Harvey (age 22), Hunter (age 18), and twins Harrison and Helena (age 4).

Herman - Attends Texas Tech University full-time. As of December 31, 2013, he has completed 31/2 years and is on schedule to graduate in May, 2014. During 2013, he earned $\$ 4,300$ working during the summer. Herman has never been convicted of a felony for possession or distribution of a controlled substance. During 2013, Hercules and Henrietta paid the following to Texas Tech for Herman's education:

$\begin{array}{lll}\text { Tuition \& fees } & - & \$ 16,000 \\ \text { Books } & -- & \$ 2,300 \\ \text { Room \& Board } & -- & \$ 9,000\end{array}$

Hermione - Attends Texas Christian University full-time. Like her brother, as of December 31, 2013, Hermione has completed 31/2 years and is on schedule to graduate in May, 2014. During 2013, she earned $\$ 4,200$ working full-time during the summer and part-time during the school year. Hermione has never been convicted of a felony for possession or distribution of a controlled substance. During 2013, Hercules and Henrietta paid the following to Texas Christian University for Hermione's education:

$\begin{array}{lll}\text { Tuition \& fees } & -- & \$ 36,000 \\ \text { Books } & -- & \$ 3,100 \\ \text { Room \& Board } & -- & \$ 11,900\end{array}$

Harvey - Attended the University of Texas full-time through the end of his sophomore year. During the summer of 2012, he quit college and went to work full-time at a local car wash in Lubbock. Harvey's friend owns the business and made Harvey the manager of the car wash. In addition, the friend promised Harvey that he will take him on as a partner in 5 years. However, after moving with his family in June (information about the move will follow), Harvey did not work for a few months. Then at the end of October, he began working at a car wash in his new town. During 2013, Harvey earned $\$ 25,000$. 
Hunter - Attends high school full-time. During the summer, he earned $\$ 4,100$ working as a swimming pool maintenance man.

Harrison and Helena - They live at home full-time.

Hercules and Henrietta's cash receipts for 2013 include the following:

\begin{tabular}{lr}
\multicolumn{1}{c}{ Interest - } & \\
City of San Antonio bonds & $\$ 3,200$ \\
Ford Motor Company bonds & 2,300 \\
First National Bank certificate of deposit & 2,600 \\
Second National Bank certificate of deposit & $\underline{1,200}$ \\
Total interest received & $\$ 9,300$
\end{tabular}

On April 15, 2013 Hercules and Henrietta purchased a vacant plot of 5 acres of land for $\$ 300,000$. The address is:

528 Lakeview Drive

Lake Charles, LA 70601

Hercules and Henrietta do not plan to build on the property. Their plan is to hold the land for investment purposes as they anticipate a boom in that area's real estate market. When acquiring the property, Hercules and Henrietta took out a land loan with the First National Bank. During 2013, they paid land loan interest on the property of $\$ 11,200$. Note: Hercules and Henrietta do not make the election to include net capital gain as investment income.

During 2013, Hercules and Henrietta made numerous trips to the local race track to bet on the horses and to play the slot machines. For the year, they spent $\$ 1,200$ betting on horses and playing the machines, but only won $\$ 580$. Even though they lost more than they won, they enjoyed the recreational gambling as they often went to the track with a group of family and friends.

Henrietta has been collecting baseball cards since she was a child. As she grew, her interest grew and she expanded from collecting cards to collecting other baseball memorabilia. Henrietta now buys and sells various baseball artifacts at baseball memorabilia shows. In 2013, she attended four shows. Henrietta feels that her involvement with baseball memorabilia constitutes a hobby, not a business. Her income and expenses for the current year from this activity are as follows:

$\begin{array}{lr}\text { Revenue from sale of baseball memorabilia } & \$ 5,400 \\ \text { Expenses } & 4,300 \\ \text { Cost of goods sold } & 1,400 \\ \text { Show registration fees } & 1,300 \\ \text { Advertising and other costs } & 1,200 \\ \text { Depreciation of equipment } & \end{array}$

During 2013, both Hercules and Henrietta each contributed \$5,300 to a Traditional IRA. Neither Hercules nor Henrietta is covered by a qualified plan by the organization that employed them during 2013.

During the period January 2013 - March 2013, Henrietta spent $\$ 1,340$ exploring the feasibility of starting a pet day care business. During April 2013, she decided not to pursue this venture.

During the Spring of 2013, Hercules and Henrietta decided to move the family to Corpus Christi so that they could be closer to their extended family. At the start of 2013, the family lived in Lubbock, TX. Hercules worked for the CPA firm Able, Baker, \& Charlie, 961 S. Shallowater Drive, Lubbock, TX 79403, while Henrietta 
worked at TD Ameritrade's Lubbock office, 369 N. Deepwater Drive, Lubbock, TX 79404. In June 2013, Hercules resigned from Able, Baker, \& Charlie and began working at his current position with Dewey, Cheatum, \& Howe in Corpus Christi. At Henrietta's request, TD Ameritrade transferred Henrietta from its Lubbock office to its Kingsville office. On 6/16/13, Hercules and Henrietta sold the family's house in Lubbock. Hercules and Henrietta had jointly purchased the house shortly after they were married. The address of the house sold is:

8756 Sam Houston Way

Lubbock, TX 79402

Hercules and Henrietta had originally purchased the house on 6/1/89 at a cost of $\$ 150,000$. Most of the house expenditures over the last 24 years involved repairs and maintenance. However, Hercules and Henrietta spent $\$ 20,000$ in 1999 to construct an addition to the back of the house, $\$ 17,000$ in 2003 to install central air conditioning, and $\$ 13,000$ in 2007 to replace their entire roof. Hercules and Henrietta sold the house for $\$ 800,000$, after spending $\$ 5,000$ fixing up the house getting it ready for sale. When selling the house, Hercules and Henrietta paid broker's commission of $\$ 48,000$, plus legal and document processing fees of $\$ 2,000$.

Hercules and Henrietta hired the Mayflower Moving Company to do the bulk of the moving. On 6/15/13, Mayflower packed all of the family's household goods and personal effects into a moving van. The family stayed in a hotel in Lubbock on 6/15, then, after completing the sale on the morning of 6/16, packed up the family's three cars -- a mini-van, a 4-door sedan, and a sport utility vehicle -- and drove the 584 miles from the old house in Lubbock to the new house in Corpus Christi. Hercules and his two oldest sons drove the 3 cars. The family stayed in a hotel in Corpus Christi on both 6/16 and 6/17. The Mayflower Company unloaded the family's belongings into the new house on 6/18. Hercules and Henrietta spent the following amounts while moving. (None of the amounts was reimbursed to them.)
Mayflower Moving Company charge
$\$ 16,300$
Meals
600
Lodging
780

On 6/17/13, Hercules and Henrietta purchased the family's new house on 8426 North Carancahua Street. The purchase price was $\$ 890,000$. To buy the new house, Hercules and Henrietta took out a mortgage loan of $\$ 300,000$ with the Second National Bank. In order to obtain a lower interest rate, Hercules and Henrietta paid 3 points, 2 of which represented prepaid interest and 1 that represented appraisal fees. In addition, they paid the following closing costs at the time of purchase:

Legal fees, transfer taxes, and document preparation fees

Title insurance

Property and casualty insurance premiums

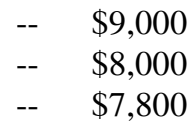

In Lubbock, the county's real property tax year is the calendar year: January 1 to December 31 . Payment for the year is due on January $31^{\text {st }}$. For the Lubbock residence, on 1/31/13, Hercules and Henrietta paid $\$ 7,300$ for the 2013 real property taxes charged to that residence. In Corpus Christi, the county's real property tax year is also the calendar year. However, payment in Corpus Christi is not due until August $31^{\text {st }}$. For the Corpus Christi residence, on $8 / 31 / 13$, Hercules and Henrietta paid $\$ 5,475$ for the 2013 real property taxes charged to that residence.

A storm on 11/21/13 caused extensive damage to the Corpus Christi residence. As a result of the storm, before making repairs, the estimated market value of the property declined from $\$ 820,000$ to $\$ 780,000$. Repairs cost $\$ 28,000$, of which $\$ 15,000$ was reimbursed by insurance.

During 2013, Henrietta, at the encouragement of her new boss in Kingsville, decided to pursue a master's degree in finance. On 15 nights during September - December, she traveled from her TD Ameritrade office to Texas A\&M University-Kingsville to attend a 3-hour graduate class. The school is located 3 miles from her office and 42 miles from her home. She spent $\$ 2,600$ on tuition, $\$ 250$ on textbooks, $\$ 150$ on a student technology fee (required), and $\$ 80$ on parking. 
At the end of November 2013, Hercules purchased a new 2014 Italian sports car. The purchase price of the car was $\$ 50,000$. In addition to the purchase price, Hercules also paid the $6.25 \%$ Texas sales tax. (Assume that neither Lubbock nor Corpus Christi charges a local sales tax.)

Although her employer suggested that Henrietta attend a 2-day convention in December in New Orleans about current developments in the financial analyst profession, Henrietta was not reimbursed for the following travel expenses:

$\begin{array}{lc}\text { Airline tickets } & \$ 760 \\ \text { Convention Fee } & \$ 334 \\ \text { Airport parking } & \$ 30 \\ \text { Taxi } & \$ 70 \\ \text { Hotel } & \$ 280 \\ \text { Meals } & \$ 100 \\ \text { Round trip mileage to/from the airport } & 60 \text { miles }\end{array}$

Henrietta estimates that she drove her car a total of 18,000 miles during the year.

Henrietta is a member of a union at TD Ameritrade. Her union dues are $1 \%$ of her gross salary and are withheld from her paycheck. Henrietta also spent $\$ 120$ in 2013 subscribing to various professional publications that she feels help her keep up-to-date with current developments in her profession. In addition, Henrietta is a member of a professional organization in which she paid dues of $\$ 340$ during 2013. The dues payment was not reimbursed by her employer. Further, in December, Henrietta bought a Christmas ham for each of the 3 employees who work directly for her, plus her secretary. The hams cost $\$ 16$ each.

Hercules and Henrietta's cash payments for 2013 include the following:

Home mortgage loan interest (Form 1098 received from lending institution) -

Prior residence

Current residence (does not include points paid)

$\$ 5,900$

7,800

Charitable contribution (statement received from the charity)

390

Tax preparation fees for 2012 federal, state, and local income tax returns

890

In order to enable Hercules and Henrietta to work full-time, they put both of their 4-year old twins, Harrison and Helena, into a day care facility when working during the week. When living in Lubbock, this is the facility used:

Tiny Tots

703 West Nields Street

Lubbock, TX 79411

EIN: $13-1235678$

When living in Corpus Christi, this is the facility used:

The Goddard School

630 Sugars Bridge Road

Corpus Christi, TX 78409

EIN: 14-1234678

During 2013, Hercules and Henrietta paid \$6,300 to Tiny Tots, and \$7,100 to The Goddard School.

Relevant social security numbers are as follows: 


\author{
Hercules Hoomanawanui \\ Henrietta Hoomanawanui \\ Herman Hoomanawanui \\ Hermione Hoomanawanui \\ Harvey Hoomanawanui \\ Hunter Hoomanawanui \\ Harrison Hoomanawanui \\ Helena Hoomanawanui
}
210-03-0132
321-13-1243
432-23-2354
543-33-3465
$654-43-4576$
$765-53-5687$
$876-63-6798$
776-73-7809

\section{Tax Computation}

Ignoring the alternative minimum tax, prepare Hercules and Henrietta's federal income tax return for 2013. Consider including the following forms and schedules with the return:

- $\quad$ Forms 1040, 2106, 2441, 3903, 4684, 4952, 8863, 8917, and 8949

- Schedules A, B, and D

The solution to the return shows that Hercules and Henrietta are owed a total refund of \$1,282.

\section{Hints}

1. If the information requested by the IRS does not fit in the allotted space on a tax form, include the information on a schedule attached to the back of the return. Be sure to reference the attached schedule on the form by writing something like "See Attached Schedule." Make sure the attachment ties into the form.

2. Assume that the taxpayers do not keep copies of receipts on purchases made during the year. Therefore, if deducting sales tax is an issue, use the Optional State Sales Tax Table included with the instructions for Schedule A. The Schedule A instructions also explain the procedure for computing the sales tax deduction.

3. How to report the purchase and sale of a residence is explained in the following 3 places:

a. "Part Three" of IRS Publication 17, Your Federal Income Tax;

b. IRS Publication 523, Selling Your Home; and

c. The instructions for Form 1040, Schedule D.

4. During the year, Hercules and Henrietta sold a residence and purchased a residence. The real property taxes applicable to both homes have to be apportioned between the buyer and seller to determine the amount that is deductible on Schedule A. This concept is explained on page 26 in IRS Publication 523 (2013).

5. Deducting transportation costs as an educational expense is explained on page 195 of IRS Publication 17 (2012), Your Federal Income Tax.

6. If a capital gain moves a taxpayer from the $15 \%$ tax bracket into the $25 \%$ tax bracket, it could change the applicable long-term capital gain alternative rate.

7. The main address for both the University of Texas and Texas Christian University can be obtained from the school's website. On Form 8863, ignore the questions about receiving Form 1098-T and the institution's federal identification number.

8. If a form or schedule is not applicable (not required by the IRS), it does not have to be included with the return.

\section{LIMITATIONS, CONCLUSIONS, AND FUTURE RESEARCH}

As to be expected, limitations exist and should be recognized. If the assignments are returned to students, then the potential exists for students to copy the prior semester's solution. However, this obstacle can be overcome by changing the amounts, revising the facts, and adding/subtracting a couple of concepts each semester. In addition, schools that have adopted the AICPA Model Tax Curriculum tend to focus on business planning rather than individual tax compliance. Our teaching tool might not appeal to an instructor who has adopted this approach. Further, our teaching assignment is designed to be a late-semester assignment when covering individual federal 
income taxation. An instructor could use the assignment earlier in the semester by modifying concepts such as including business income and expenses, or rental income and expenses. Finally, the IRS forms change each year. Plus, there are inflation adjustments, rate changes, and other revisions to the tax law most years. However, the concepts rarely change. The case presented in this paper could be used as a template for many years. Tax instructors will find this assignment to be an effective alternative to using an assigned problem from a tax text.

Other concerns one can address are how effective is it to develop a stand alone tax return assignment? Is learning enhanced through the use of realistic, professor-developed assignments of any kind, not just tax return assignments? Answering these questions provide direction for further research.

\section{AUTHOR INFORMATION}

Kevin E. Flynn, PhD, CPA, is an associate professor at West Chester University of Pennsylvania. He worked for seven years in public accounting in the Philadelphia offices of Ernst \& Young and PriceWaterhouseCoopers. Subsequently, Kevin worked in industry as a financial reporting manager, assistant controller, and controller before entering academia full time in the fall of 1993. He earned his PhD in Accounting at Drexel University. He primarily teaches individual and business federal income taxation. His research interests involve individual income taxation. E-mail: kflynn@wcupa.edu (Corresponding author)

Phyllis A. Belak, MBA, CPA, CFE is an accounting instructor at West Chester University of Pennsylvania. She previously worked in industry as a financial analyst and senior financial analyst and for a firm preparing individual and business federal and state tax returns. Phyllis earned her MBA from Drexel University. She primarily teaches not-for-profit and governmental accounting, and fraud examination for managers. Her research interests include individual income taxation and fraud.

Glenn S Soltis, MBA, CPA, is an accounting instructor at West Chester University of Pennsylvania. He earned his undergrad degree from Villanova University and his masters degree from Drexel University. He has worked in public accounting in audit and consulting services, and in industry as a CFO and CEO. He teaches numerous accounting courses including financial accounting and international accounting.

\section{REFERENCES}

1. CCH (Commerce Clearing House) (2013). 2013 U.S. Master Tax Guide. Published by PricewaterhouseCoopers.

2. Internal Revenue Service (2013). Your Federal Income Tax For Individuals: Publication 17. 11/26/2013.

3. Internal Revenue Service. (2013). Selling Your Home: Publication 523. 1/5/2014.

4. Nellen, A., Kern, B., \& Dennis-Excoffier, S. (2004). Current status of the tax curriculum in accounting programs. The Tax Adviser, 35(11), 712-714.

5. Smith, K., Davy, J., \& Rosenberg, D. (2009). The influence of motivation and attitude on cheating behavior among accounting majors. (Unpublished Working Paper). 


\section{APPENDIX A}

\section{Teaching Notes}

1. We tested this case in different introductory federal income tax classes from 2009 to 2013. By testing the assignment with actual students, we learned how important it was to give the hints that were stated earlier in the "Tax Computation" section.

Hint \#1 (attachments) - This hint teaches students how to attach data to the back of a return. This concept is not explained in a textbook and is not always easily found in the IRS instructions. Without this hint, students struggle learning this concept.

Hint \#2 (state \& local income tax versus sales tax) - Students struggle with compliance in this area and need to be pointed in the right direction.

Hint \#3 (purchase and sale of a residence) - Students need help getting started with this concept.

Hint \#4 (property tax apportionment) - Without this hint, most students would miss this concept.

Hint \#5 (deducting transportation costs as an educational expense) - Again, without this hint, most students would miss this concept.

Hint \#6 (taxation of long-term capital gain) - Again, without this hint, most students would overlook this concept.

Hint \#7 (university address) - The point of the assignment is to understand tax compliance. Therefore, providing students with this hint so they are not stumped seems to be worthwhile.

Hint \#8 (including forms or schedules) - Without this hint, students often include unnecessary forms and schedules.

2. Students often get confused and frustrated when determining which forms and schedules to include with the return and have a hard time getting started. Stating on the "Tax Computation" page which forms and schedules should be considered when preparing this return gives students enough guidance to keep them focused on learning, without giving too much information.

3. Credits were emphasized in this case. Two of the most common credits available to taxpayers are the education tax credits: the American Opportunity Credit (AOC) and the Lifetime Learning Credit (LLC). We also wanted to make an AOC or LLC phaseout computation part of the assignment. However, the adjusted gross income (AGI) thresholds for the two phaseout computations are different amounts, thus forcing us to choose one credit or the other. We chose to include the AOC credit because it fit well with the facts (a married couple with multiple dependents). Unfortunately, by making the couple's adjusted gross income fall in the range that would cause the AOC credit phaseout computation, the LLC and Child Tax Credit became completely phased out. (In 2013, for a married couple filing a joint return, the AGI phaseout range for the LLC is $\$ 107,000-\$ 127,000$, and for the Child Tax Credit is $\$ 110,000-\$ 130,000$.) Modifying the facts so that the LLC and Child Tax Credit phaseout computations are applicable could be part of a future assignment.

4. This case includes a long-term capital gain (LTCG) that is taxed at an alternative rate. When computing the taxpayer's tax liability, the actual tax return, Form 1040, does not have a separate line for computing the liability on income taxed at LTCG alternative rates. The Form 1040 instruction booklet provides a table that students can use to walk through the calculation. However, in the first tests of the assignment, many students missed this computation. Therefore, during the subsequent tests, we chose to emphasize the concept in class. An instructor using this case could choose to emphasize the concept in class, or provide students with a hint, just like we provide the hints on our "tax computation" page. 
5. Hercules and Henrietta borrowed money to purchase investment property. The deductible amount of interest expense on the loan is limited to net investment income. However, taxpayers have the option of including net capital gains in investment income. If taxpayers choose this option, then they reduce the amounts qualifying for LTCG alternative rates (CCH, 2013, Paragraph 1094). We wanted the alternative rates to be part of the assignment. Therefore, in the assignment's facts we stated "Hercules and Henrietta do not make the election to include net capital gain as investment income." Also, even though investment income is a concept covered in an earlier assignment, we chose to include investment income so that the taxpayers would have an investment interest expense deduction.

6. Hercules and Henrietta sell and buy a principal residence. The real property taxes applicable to both residences have to be apportioned between the seller and buyer to determine the property tax deduction on Schedule A (CCH, 2013, Paragraph 1032). Since Hercules and Henrietta paid the buyer's portion of property tax on the Lubbock residence, they get to recognize this payment by reducing the sales price by the amount of the payment apportioned to the buyer. Hercules and Henrietta also paid the seller's portion of property tax on the Corpus Christi residence. They recognize the amount by adding it to their basis in the property, thereby not affecting the 2013 return (IRS Publication 523, page 26).

7. When selling their principal residence, Hercules and Henrietta paid a broker's commission totaling $\$ 48,000$. This amount is computed by multiplying the sales price by $6 \%$, which is a typical broker's commission percentage. In addition, legal and document processing fees paid totaled $\$ 2,000$. Consequently, total selling expenses were $\$ 50,000$ and are subtracted from the selling price to determine the amount realized (IRS Publication 17, page 110). The computation of the realized gain is shown here and in "Note 1" in the "Solution" section.

Sales price
Property taxes paid by seller, apportioned to the buyer
Adjusted sales price
Less: Selling expenses
Amount realized
Less: Adjusted basis
Realized gain

$$
\begin{aligned}
& \$ 800,000 \\
& \text { (3,980) } \\
& \$ 796,020 \\
& (50,000) \\
& \$ 746,020 \\
& (\underline{200,000)} \\
& \$ \underline{\underline{546,020}}
\end{aligned}
$$

The sale of the residence is included on Form 8949. However, Form 8949 does not have a place for "amount realized." Form 8949 has a column for "proceeds (sales price)," a column for "cost or other basis," and a column for "gain or loss." The IRS instructions are not clear whether the selling expenses should be subtracted from the sales price column, or added to the basis column. Ultimately, it does not matter because the gain amount will be the same. Interestingly, about half the students subtract the selling expenses from the sales price column, and the other half add selling expenses to the basis column.

8. Paying points when obtaining a mortgage loan is common. Typically, the points paid by the person(s) obtaining the loan represent either fees, prepaid interest, or both. However, the tax treatment for fees other than loan origination fees (not currently deductible) is different than the tax treatment for prepaid interest (deductible when purchasing a principal residence). Specifically, when points paid represent the payment of certain fees such as appraisal fees, the payment is not currently deductible (IRS Publication 17, pages 156-157; also CCH, 2013, Paragraph 1055). This concept is not always stated clearly in a text and we feel it is important to include both types of points. 


\section{APPENDIX B}

\section{Solution}

Income

Salary $[\$ 79,000+67,000]$

$\$ 146,000$

Income -

City of San Antonio Bonds - Excluded Ford Motor Company Bonds

First National Bank Certificate of Deposit

Second National Bank Certificate of Deposit

$\$ 0$

2,300

2,600

1,200

Sale of residence (Note 1)

Hobby Income

Gambling Winnings

Total Income

Less: Deductions For AGI

Moving Expenses (Note 2)

Tuition Deduction [AGI exceeds the limit]

Contribution to Traditional IRA $[\$ 5,300+\$ 5,300]$

Adjusted Gross Income (AGI)

Less:

Itemized Deductions (Note 3)

Personal and Dependency Exemptions (Note 4)

Taxable Income

$(27,300)$

$\$ 94,493$

Tax Liability (Note 5)

$\$ 9,678$

Less:

American Opportunity Credit (Note 6)

Child Care Credit [ $\$ 6,000 \times 20 \%$ ]

Withholdings [ $\$ 4,740+\$ 4,020]$

$\$ \quad 1,000$

1,200

8,760

Net Tax Payable (or Refund Due)

$(\$ 1,282)$ 


\section{Notes}

(1) Sale of Lubbock Residence:

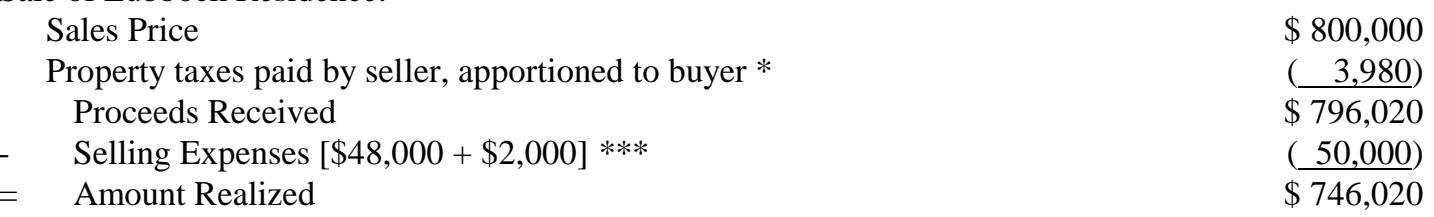

- $\quad$ Adjusted Basis:

Cost

$\$ 150,000$

Add: Capital Additions

$$
[\$ 20,000+\$ 17,000+\$ 13,000]
$$

50,000

$=\quad$ Realized Gain

$\$ 546,020$

$(\underline{500,000)}$

- $\quad$ \$121 Exclusion [Married Filing Jointly]

$\$ \underline{46,020}$

* The sales price is reduced by the amount of real estate taxes paid by the seller that are apportioned to the buyer.

Real Property Taxes paid by Hercules and Henrietta

Times $\%$ of year house is owned by buyer $* *$

Reduction in Sales Price

** Days owned by buyer [June 16 - December 31]

Total days in 2013

365 days

*** Fixing-up expenses are not deducted.

(2) Moving Expenses

Deductible Expenses:

Cost to move household goods and personal effects

Lodging

$\$ 16,300$

780

Travel [Mileage x Mileage Allowance]

[584 miles x 3 vehicles x \$.24 per mile]

Total deduction

$\frac{420}{17,500}$

The cost of meals is not deductible.

(3) Itemized deductions:

State \& Local Income Tax $[\$ 0+\$ 0+\$ 790+\$ 670]$

$\$ 1,460$

Note: Texas does not have a state income tax.

Sales Tax: [Sales Tax Table]

$\$ 1,739$

[Car Purchase $(\$ 50,000 \times 6.25 \%)] \quad \underline{3,125}$

4,864

Greater of State \& Local Income Tax or Sales Tax

$\$ 4,864$

Real property tax on personal residences

Lubbock residence $[\$ 7,300 \times$ (166 days/365 days)]

Corpus Christi residence [6/17/13 - 12/31/13]

[ $\$ 5,475 \times$ (198 days / 365 days $)]$

$\$ 3,320$

$\underline{2,970}$

Home mortgage loan interest $[\$ 5,900+\$ 7,800]$

$\$ 13,700$

6,000

6,290

Add: points paid $[\$ 300,000 \times .02]$

19,700 
Investment interest [Deduction limited to Net Invest. Inc.]

6,100

Charitable contributions

Casualty Loss

$\begin{array}{lr}\text { Loss }[\$ 820,000-\$ 780,000] & \$ 40,000 \\ \text { Less: Insurance Reimbursement } & (15,000) \\ \text { Less: Floor } & (\underline{100)}\end{array}$

Net Casualty Loss

24,900

$(\underline{17,600)}$

Less: $10 \%$ of AGI Floor [ $\$ 176,000 \times 10 \%$ ]

7,300

Miscellaneous Itemized Deductions

Job-Related Expenses - Henrietta

Graduate School:

Tuition, Fees, and Books

Vehicle Expenses [675 miles x \$.565/mile]

$\$ 3,000$

381

Parking

2-Day Convention

Airline Tickets + Convention Fee

Airport Parking + Taxi + Hotel

Meals [ $\$ 100 \times 50 \%]$

Vehicle Expenses [60 miles x \$.565/mile]

Union dues [ $\$ 67,000 \times 1 \%]$

Professional publications -120

Membership dues 340

Business Gifts - Hams [\$16 x 4]

Total Job-Related Expenses

Tax preparation fees

Hobby Losses [to extent of Hobby Income]

Less: $2 \%$ of AGI $(\$ 176,000 \times 2 \%)$

Total Misc. Itemized Deductions

Other Itemized Deductions - Gambling Losses

Itemized Deductions
1,094

50

34

670

340

(4) Personal and Dependency Exemption Summary:

Hercules - Personal Exemption

Henrietta - Personal Exemption

Herman - Qualifying Child (QC)

Full-Time Student: Therefore, he meets the Age Test.

Gross Income Test is not applicable for QC classification.

6,213

890

5,400

$\underline{(3,520)}$
8,983

580

$\underline{\$ 54,207}$

$\$ 3,900$

3,900

3,900

3,900

0

3,900

3,900

$\underline{3,900}$

$\$ \underline{\underline{27,300}}$ 
(5) Filing status is Married Filing Jointly

Taxable Income

$\$ 94,493$

Less: Long-Term Capital Gain (LTCG) -- Sale of Residence

$(46,020)$

Amount taxed at Ordinary Income (OI) Rates

$\$ \underline{\underline{48,473}}$

Tax on OI using the Tax Rate Schedule

$[\$ 1,785.00+.15(\$ 48,473-\$ 17,850)]$

Tax on OI using the Tax Table

$\$ 6,378$

$6,379 \$ \quad \$ \quad 6,379$

Tax on LTCG $[(\$ 72,500-\$ 48,473) \times 0 \%]$

Tax on LTCG $[(\$ 94,493-\$ 72,500) \times 15 \%]$

Tax Liability

$\$ \frac{3,299}{9,678}$

(6) American Opportunity Credit (AOC)

Herman

\begin{tabular}{rr}
$1^{\text {st }} \$ 2,000$ of Tuition paid & $\$ 2,000$ \\
$+\quad 25 \%$ of next $\$ 2,000$ of Tuition paid & 500 \\
\hline
\end{tabular}

$=$ Unadjusted AOC for Herman

$\$ 2,500$

Hermione

$1^{\text {st }} \$ 2,000$ of Tuition paid

$\$ 2,000$

$+\quad 25 \%$ of next $\$ 2,000$ of Tuition paid

500

$=$ Unadjusted $\mathrm{AOC}$ for Hermione

Total Unadjusted Credit

Less: Phaseout

$[(\$ 176,000-\$ 160,000) / \$ 20,000]$ x $\$ 5,000$

Adjusted AOC

(7) Line 2(A), Form 4684 - Basis of the new residence

Cost

$\$ 890,000$

9,000

Legal fees, transfer taxes, and document preparation fees

8,000

Title insurance

Property \& casualty insurance premiums *

Property taxes paid by buyer that applied to seller

$\$ 5,475 \times$ ( 167 days / 365 days) [1/1/13 - 6/16/13]

2,505

Basis of the new residence

$\$ \overline{909,505}$

* In accordance with the instructions in Part Three of IRS Publication 17, mortgage and casualty insurance premiums paid at the time of purchase are specifically excluded from being added to the property's basis.

(8) Investigation of a business expenses

The expenses paid when exploring the feasibility of starting a pet day care business are not deductible since the business is unrelated to Henrietta's current field and the business was not started. 


\section{APPENDIX C}

\section{Tax Return}

For a copy of the pdf file that contains the tax return that goes with this case, please contact the author. 